\title{
Wpływ obiektów głęboko posadowionych na strukturę strumienia filtracji wód podziemnych w obszarze wrażliwym na zmiany warunków hydrogeodynamicznych
}

\author{
Konrad Opęchowski ${ }^{1}$, Ewa Krogulec ${ }^{1}$
}

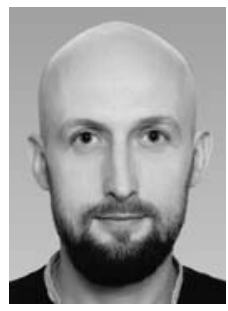

K. Opęchowski

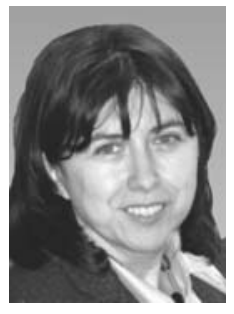

E. Krogulec

Impact of deep foundations on the groundwater flow structure in the hydrogeodynamically vulnerable area. Prz. Geol., 67: 478-486; doi: 10.7306/2019.37

A b s tr a c t. The progressive citification of urban spaces results in compacting buildings and deeper foundation of new objects, and even deepening of existing facilities - to obtain maximum use of underground space. This process significantly interferes with the geological environment, both in the local (single deep foundation objects) and district (linear objects such as subways, tunnels, sewage collectors, groups of deep foundation objects). In Warsaw, underground urbanization extends several dozen meters deep and reaches the upper parts of the Neogene deposits, often fully intersecting Quaternary deposits. The progressing urbanization, and in particular the cumulative influence of deep foundation structures, creates a new set of factors with a potentially significant impact on the hydrogeological conditions of the Quaternary aquifer, including also the deep-seated aquifer, so far not having placed under a direct hydrogeodynamic impact. This article presents an assessment of the impact of underground development on the groundwater flow structure, with a particular emphasis on the deformation of the filtration mesh as a permanent result of object built-in into the groundwater stream. The analysis is based on the real case study of the implementation of a building located in the area vulnerable to hydrogeodynamic changes, where additionally can occur a cumulative impact with underground subway tunnels. Model simulations of the building foundation impact on the hydrogeodynamic conditions of the environment were performed. The results of prognostic model calculations were compared with the observations of changes in the groundwater level during construction works. The results indicate slight, permanent changes in groundwater levels, an increase in hydraulic gradients and changes in water flow directions. The scope of the changes was considered safe for the environment and building objects, allowing even a deeper foundation, although not devoid of the need for a long-term observation of groundwater levels. The obtained results indicate the usefulness and utilitarianity of numerical modeling methods in the analysis of hydrogeological conditioning of deep foundations.

Keywords: dam effect, deep foundation, groundwater flow structure, groundwater level monitoring, cumulative impacts, urbanization, Warsaw

Zabudowa miejska powoduje zaburzenia w obiegu wód podziemnych (Jeż i in., 1995), które rozpatruje się między innymi w kontekście zmian stanów oraz spadków hydraulicznych tych wód, i w ich konsekwencji możliwych innych wpływów zabudowy na środowisko. Zmiany warunków hydrogeologicznych wywoływane przez zabudowę miejską, a w szczególności dotyczące hydrodynamiki wód podziemnych, są trudne do monitorowania (Kazimierski, Paczyński, 2005; Małecki, 2013). Krótki czas realizacji obiektów budowlanych często wyklucza długoterminowe badania monitoringowe stanów wód podziemnych, umożliwiające wskazanie zakresu zmian stanów, ich dynamikę oraz identyfikację wpływu zabudowy na warunki wodne. Jednocześnie $\mathrm{z}$ uwagi na wolne tempo zabudowy miast dotychczas nie zauważano lub ubocznie traktowano oddziaływania wynikające $\mathrm{z}$ przyrostu zabudowy podziemnej, w szczególności głębokiego fundamentowania kubaturowych obiektów wysokościowych (Ding i in., 2008; Jiao i in., 2008). Tymczasem z końcem XX w. wraz z rozwojem gospodarki wolnorynkowej w największych polskich aglomeracjach miejskich nastapiła znacząca intensyfikacja zabudowy i potrzeba zagęszczania przestrzeni. Równocześnie $\mathrm{z}$ przyrostem wysokościowego zasięgu obiektów powiększa się również ich zasięg powierzchniowy i głębokościowy. Powszechnie buduje się kilkukondygnacyjne garaże podziemne - stały się one nieodłącznym elementem konstrukcji obiektów. W Polsce najwięcej obiektów głęboko posadowionych powstaje w Warszawie, gdzie w zwartej zabudowie miejskiej są obecnie wznoszone budynki posiadające do sześciu kondygnacji podziemnych. Tak duża głębokość posadowienia, a także powierzchnia zabudowy oraz kumulacja oddziaływań wielu blisko siebie wzniesionych budowli ingerują w naturalną hydrodynamikę wód podziemnych.

Wbudowanie obiektu w strumień wód podziemnych może prowadzić do trwałych zaburzeń naturalnych warunków hydrogeodynamicznych środowiska na skutek zmian warunków przepływu wód (efekt tamy) i zasilania infiltracyjnego warstwy wodonośnej (uszczelnienie powierzchni oraz skoncentrowane wprowadzanie wód opadowych do warstwy wodonośnej). W skrajnym przypadku może dochodzić do hydraulicznego zniszczenia podłoża, zgodnie z normą Eurokod 7 (PN-EN 1997-1:2008-05P Eurokod 7: Projektowanie geotechniczne), rozumianego jako zbiór niekorzystnych zjawisk filtracyjnych: wyparcia lub zniszczenia struktury gruntu (hydraulicznego unoszenia cząstek gruntu, erozji wewnętrznej lub przebicia hydraulicznego).

\section{CEL BADAŃ}

Celem badań była ocena wpływu zabudowy podziemnej na strukturę strumienia filtracji wód podziemnych (Kro-

\footnotetext{
${ }^{1}$ Wydział Geologii, Uniwersytet Warszawski, ul. Żwirki i Wigury 93, 02-089 Warszawa; k.opechowski@student.uw.edu.pl; ewa.krogulec@uw.edu.pl
} 
gulec, 1997) na etapie eksploatacji obiektu budowlanego, ze szczególnym uwzględnieniem deformacji siatki filtracyjnej. Analizę uwarunkowań hydrogeologicznych i ich zmian przeprowadzono na przykładzie wielorodzinnego budynku mieszkalnego Stodowiec City, zbudowanego w Warszawie w bezpośrednim sąsiedztwie I linii metra.

\section{ZARYS ZAGADNIENIA}

Głęboko posadowione obiekty budowlane na ogół ingerują w środowisko geologiczne w sposób tak istotny, że wymagana jest analiza uwarunkowań hydrogeologicznych w celu diagnozy stanu oraz określenia możliwych zmian i ich konsekwencji (Opęchowski, 2005, 2010). Ocena zmian spowodowanych przez głębokie fundamentowanie powinna umożliwić odpowiedni dobór metod budowy obiektów w celu zminimalizowania ich negatywnego wpływu na system krążenia wód podziemnych. Analizując różne warianty fundamentowania należy wziąć pod uwage wpływ realizacji obiektu na elementy znajdujące się w strefie potencjalnych oddziaływań, a mogące skutkować między innymi zmianą kierunków i prędkości filtracji wód, zmianą stanów wód oraz innych parametrów hydrogeologicznych. Zagadnienie to jest szczególnie złożone w przypadku kumulowania się oddziaływań wielu obiektów. Dodatkowym problemem jest głębokie fundamentowanie w obszarach objętych ochroną prawna, powszechną na terenach miejskich, lub wynikającą np. $\mathrm{z}$ lokalizacji obszarów Natura 2000, GZWP, dolin rzecznych i innych tym podobnych obiektów.

W celu określenia zmian warunków hydrogeodynamicznych, które mogły powstać na skutek fundamentowania, wymagane jest stosowanie metod modelowania hydrodynamicznego. Modelowanie powinno obejmować identyfikację stanu przed rozpoczęciem prac budowlanych, wariantowy dobór metod fundamentowania, poszczególne etapy prac budowlanych, a następnie funkcjonowanie obiektu budowlanego - toteż wymaga ono znajomości metod głębokiego fundamentowania i procesów z tym związanych. Modele hydrodynamiczne powinny być weryfikowane na każdym etapie fundamentowania, a po zakończeniu prac także poprzez zaproponowany monitoring oddziaływań budowy obiektu.

W latach 80. XX w., podczas prac projektowych I linii metra $\mathrm{w}$ Warszawie stwierdzono, że w złożonych warunkach hydrogeologicznych nie istnieją lepsze metody badawcze niż badania modelowe (Szymanko, 1986; Dąbrowski, Szymanko, 1987; Zajdel, Zawadzki, 1987). Badania te należy stosować także w fazie budowy obiektu, np. do optymalnego sterowania odwodnieniem i oceny skutków jego oddziaływania. Doświadczenia z tego okresu potwierdzały istotną rolę wiarygodnych danych wejściowych do modeli i trudności w ich pozyskiwaniu.

Struktura modeli odwodnień powinna być zbliżona do struktury modeli ujęć wód podziemnych. Należy przy tym uwzględnić odpowiednią skalę i zadbać o dużą precyzję odwzorowania rzeczywistych warunków (Dąbrowski, 1997). Zróżnicowanie rozpoznania warunków hydrogeologicznych w obszarach miejskich wymaga zastosowania w modelowaniu odpowiedniej dyskretyzacji przestrzeni. Wynik wymuszenia zadanego $\mathrm{w}$ bloku jest zależny od wymiarów siatki obliczeniowej, jednak jej zagęszczanie powyżej pewnego progu nie generuje już istotnych zmian i po- winno być zaniedbane (Burzyński, Szpakowski, 2010). Przyjęcie odpowiednio oddalonych warunków brzegowych niweluje istotny wpływ na uzyskiwane wyniki (Dąbrowski, Witczak, 2011). Należy uwzględnić promień potencjalnego oddziaływania obiektu (Powers i in., 2007; Zhou i in., 2010) oraz czas trwania wymuszenia. Wskazuje to jednoznacznie, że założenia modelu dla każdego przypadku powinny być indywidualnie i świadomie dobrane $\mathrm{w}$ sposób pozwalający osiągnąć zamierzony cel.

\section{OBSZAR BADAŃ}

\section{Lokalizacja terenu badań}

Badania prowadzono w okolicy budynku mieszkalnego Słodowiec City, wzniesionego w warszawskiej dzielnicy Bielany, u zbiegu ulic Stefana Żeromskiego i Juliusza Słowackiego. Wcześniej teren ten był użytkowany przez dworzec autobusowy PKS Marymont. Analizie poddano strefę potencjalnych oddziaływań geotechnicznych nowej budowli, ograniczoną do bliskiego sąsiedztwa wykopu (w szczególności pobliski tunel metra) oraz strefę oddziaływań hydrogeologicznych, o szerszym zasięgu - w kierunku odpływu wód podziemnych obejmującą obszar w promieniu ok. 500-700 m od budynku, na którym znajduje się skarpa wysoczyzny i naturalne wysięki u jej podnóża. W sąsiedztwie Słodowiec City stoją wysokie bloki mieszkalne z lat 70. XX w., a w odległości niespełna $10 \mathrm{~m}$ od budynku przebiega tunel I linii metra (ryc. 1).

\section{Charakterystyka obiektu budowlanego}

Wielorodzinny budynek mieszkalny Słodowiec City, o długości blisko $300 \mathrm{~m}$, ma 9-11 kondygnacji nadziemnych i 2 kondygnacje podziemne. Usytuowanie obiektu jest poprzeczne do linii prądu wód podziemnych i częściowo styczne do tuneli metra. Tunele metra są posadowione na głębokości ok. $11 \mathrm{~m}$ - ok. $2 \mathrm{~m}$ płycej niż Słodowiec City. Realizację obiektu rozpoczęto w 2014 r. Budynek oddano do użytku w 2016 r. Część podziemna jest posadowiona na płycie fundamentowej na głęb. ok. $8 \mathrm{~m}$ p.p.t. Trwała obudowa wykopu, składająca się ze ścian szczelinowych niedogłębionych oraz poziomej przesłony przeciwfiltracyjnej, wykonanej w technologii iniekcji wysokociśnieniowej jet-grouting, stanowi integralną część obiektu i sięga głębokości ok. $13 \mathrm{~m}$ p.p.t., tj. ok. $7 \mathrm{~m}$ poniżej zwierciadła wód podziemnych. Część podziemna została wykonana w pół roku.

\section{Zarys budowy geologicznej i warunków hydrogeologicznych}

Obszar badań jest usytuowany na zdenudowanej, polodowcowej Wysoczyźnie Warszawskiej, w odległości ok. $400 \mathrm{~m}$ od jej krawędzi, stanowiącej skarpę o wysokości blisko $10 \mathrm{~m}$ (ryc. 2). W rejonie badań występują residualne obniżenia terenu w formie dolin erozyjnych, przebiegające poprzecznie do skarpy wysoczyzny i kontynuujące się u jej podnóża - są one pozostałością po dawnych powierzchniowych przepływach wód rzeki Rudawki. W morfologii terenu, a także na historycznej mapie geologicznej (Sujkowski, Różycki, 1936) u podnóża skarpy zarysowują się misy licznych stawów i rozlewisk, obecnie w większości suchych. 


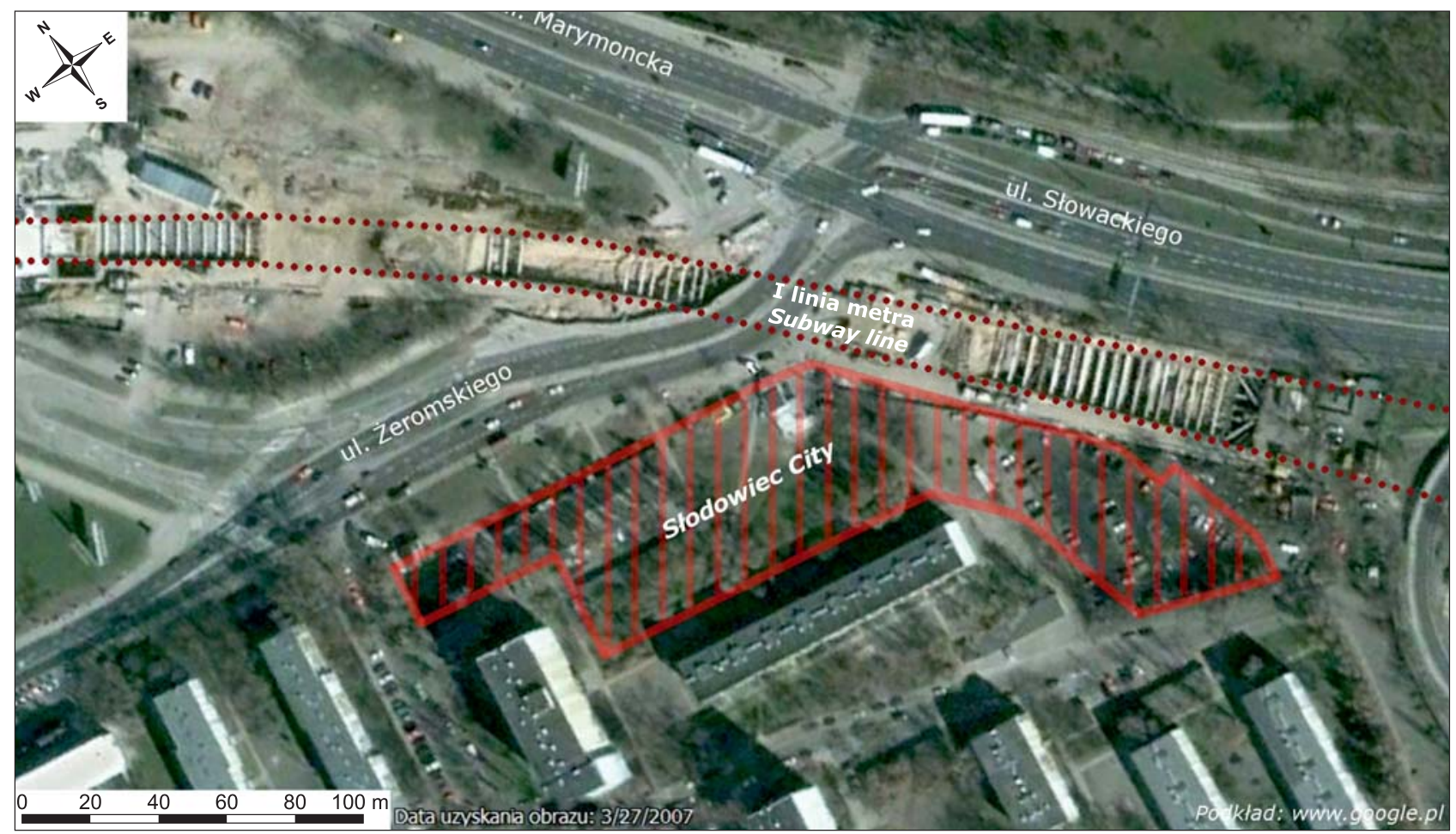

Ryc. 1. Lokalizacja budynku Słodowiec City na tle budowy I linii metra (zdjęcie z 2007 r.)

Fig. 1. Location of the object Słodowiec City against a background of subway construction site (picture taken in 2007)

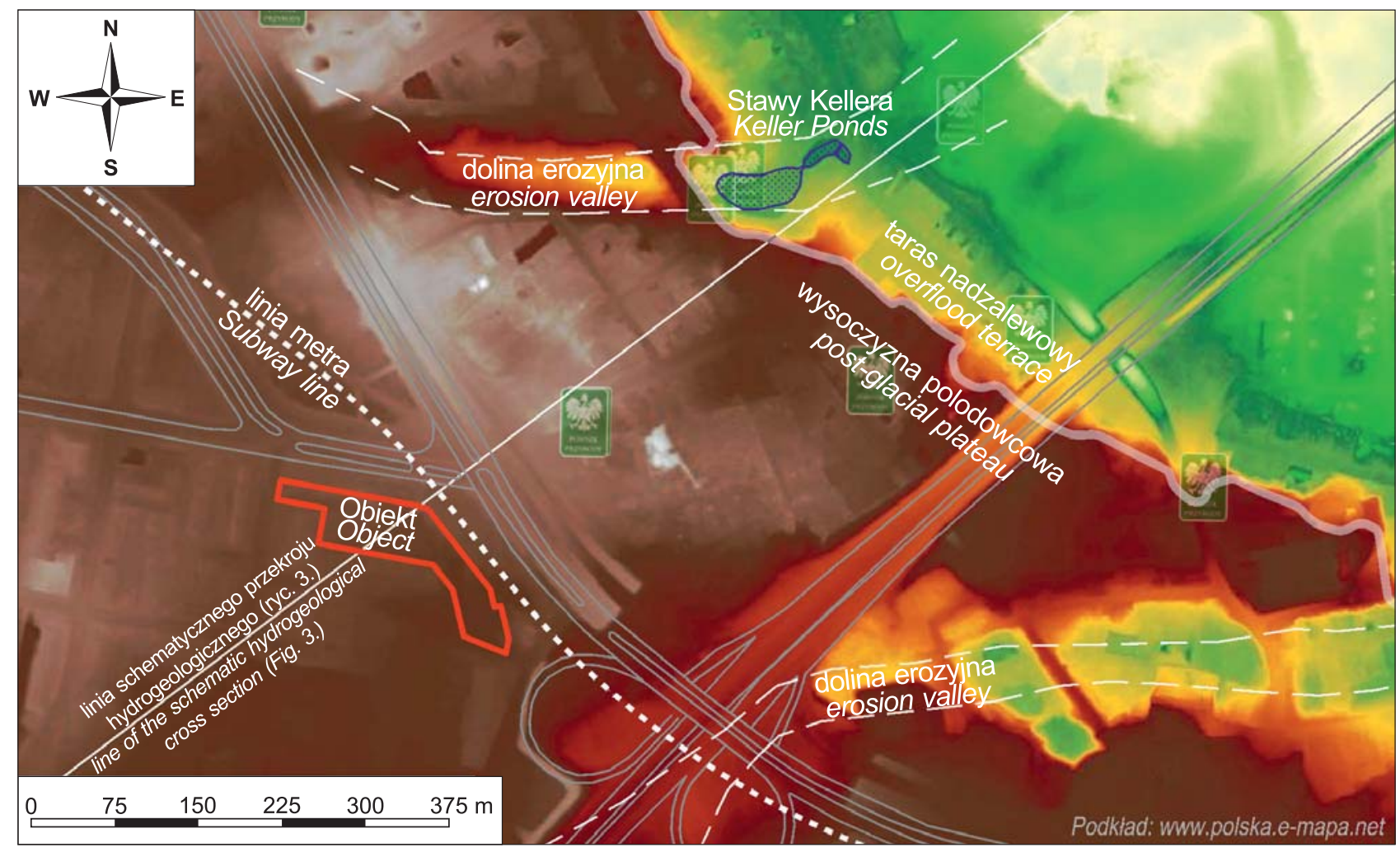

Ryc. 2. Mapa geomorfologiczna rejonu budowy Słodowiec City

Fig. 2. Geomorphological map of the area of the Słodowiec City

Dwa z tych stawów, wypełnione woda, znajdują się w parku o nazwie Stawy Kellera. Są one cenne przyrodniczo i stanowią współczesny przejaw przepływów skarpowych. Dalej wody skarpowe odpływają w kierunku starorzecza Wisły.
Historyczne uwarunkowania użytkowania terenu wokół Rudawki oraz funkcjonowanie Stawów Kellera wskazują, że procesy związane ze spływem wód skarpowych były i nadal są istotnym elementem bilansu wodnego 
tego terenu. Doświadczenia z prowadzenia robót odwodnieniowych, m.in. podczas budowy I linii metra, kiedy to doszło do czasowego całkowitego zaniku naturalnego zasilania stawów, stanowią bezpośrednie potwierdzenie szczególnej wrażliwości tego terenu na zmiany hydrogeodynamiczne.

W podłożu budynku Słodowiec City występują osady czwartorzędowe o miąższości do $50 \mathrm{~m}$. Leżą one na utworach plioceńskich, których stropowa powierzchnia jest zaburzona glacitektonicznie. Sa to osady akumulacji rzecznej i wodnolodowcowej z okresu preglacjału i zlodowacenia odry, głównie piaski średnie, grube i pospółki ze żwirami i kamieniami. Gliny zwałowe zlodowaceń odry i warty zachowały się w postaci niewielkich płatów. Ponad nimi zalegają osady zastoiskowe zlodowacenia warty o miąższości do kilkunastu metrów, reprezentowane przez piaski drobne i pylaste z podrzędnymi przewarstwieniami glin pylastych i pyłów (Dawidowski, Misiurek, 2003; Łukasik, 2011; Chmielewski i in., 2012). Osady czwartorzędowe wykazują korzystne warunki do posadowienia bezpośredniego - są to grunty w stanie średniozagęszczonym, wraz z głębokością przechodzące w stan zagęszczony (Dawidowski, Misiurek, 2003; Łukasik, 2011; Chmielewski i in., 2012).

Na skutek erozji glin lodowcowych w rejonie budowanego obiektu przypowierzchniowy I poziom wodonośny połączył się z zasadniczym podglinowym II poziomem wodonośnym (ryc. 3). Miąższość wspólnego poziomu wodonośnego wynosi od 12 do $40 \mathrm{~m}$. Zasilanie następuje głównie na skutek infiltracji opadów atmosferycznych. Drenaż wód odbywa się poprzez odpływy ze skarpy Wysoczyzny Warszawskiej w kierunku tarasów Wisły. U podnóża skarpy następuje bezpośredni kontakt z aluwialną warstwą wodonośną (Ia) tarasu nadzalewowego.

Przed wybudowaniem Słodowiec City charakterystyczne stany wód podziemnych, ustalone na podstawie incydentalnych pomiarów przeprowadzonych w latach 1952-1976 (gdy badany teren był użytkowanny przez dworzec autobusowy PKS Marymont), a także pomiarów z lat 1998-2011, określono w tym rejonie na od 91,7 do 93,2 m n.p.m., przy stanie średnim wynoszącym 92,2 m n.p.m.

\section{METODYKA I ZAKRES BADAŃ}

Modelowe symulacje zmian warunków hydrogeologicznych, wykonane na etapie projektowym (prognoza), porównano z wynikami rzeczywistego położenia zwierciadła wody podziemnej, zarejestrowanymi w ramach monitoringu w trakcie budowy Słodowiec City (pomierzone). Trwałe oddziaływanie obiektu analizowano na etapie jego eksploatacji, tj. po wbudowaniu części podziemnej w strumień wód podziemnych.

\section{Prognozy modelowe}

Do symulacji modelowych wykorzystano numeryczny model obliczeniowy z pakietu programowego SWS Visual Modflow (Harbaugh, 2005). Jednowarstwowy model obej-

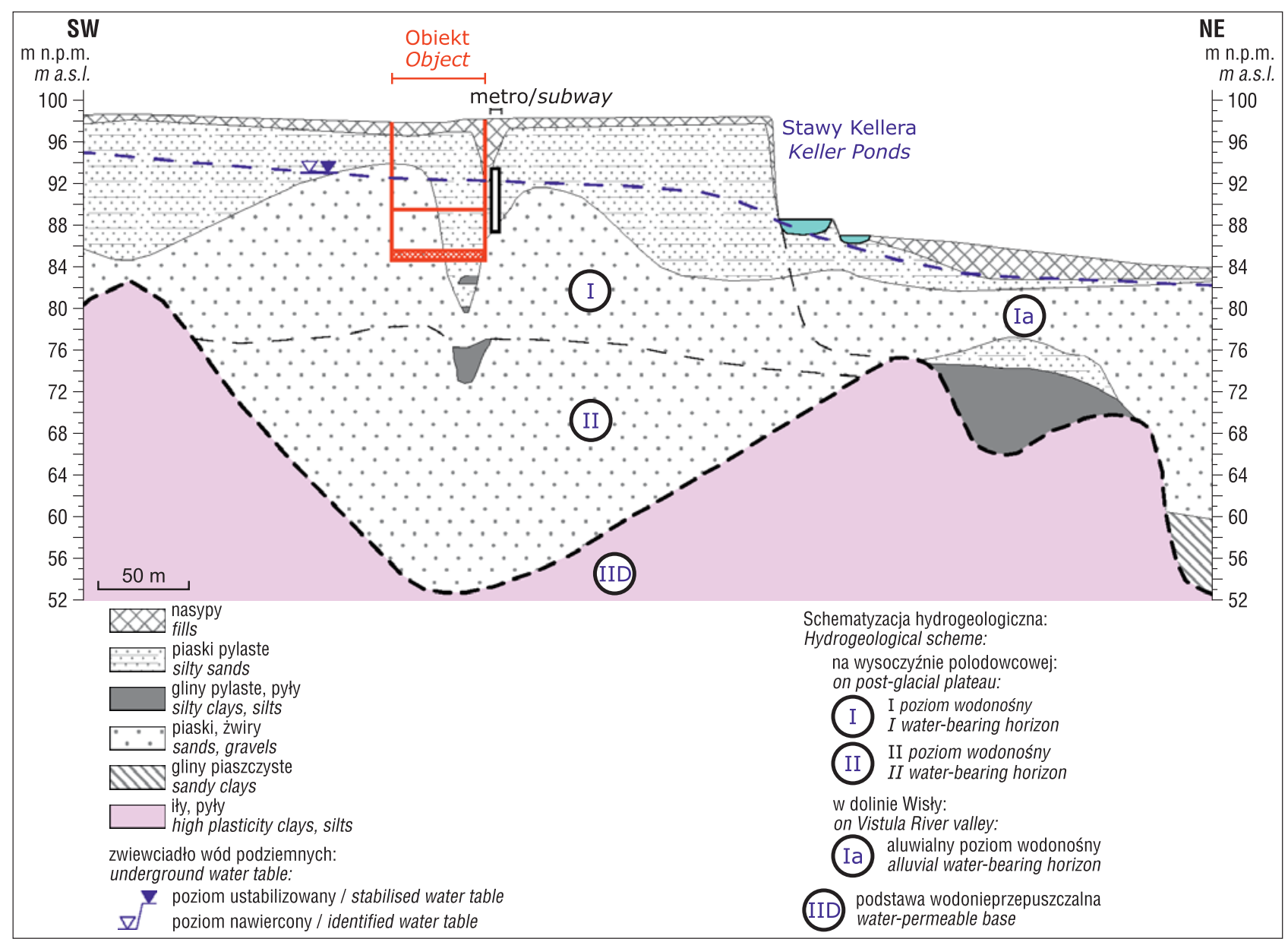

Ryc. 3. Schemat budowy geologicznej i warunków hydrogeologicznych rejonu badań

Fig. 3. Scheme of geological structure and hydrogeological conditions of the study area 
mował powierzchnię $13,3 \mathrm{~km}^{2}$ i został podzielony na bloki obliczeniowe o wielkości od $5 \times 5 \mathrm{~m}$ do $50 \times 50 \mathrm{~m}$. W modelu przyjęto warunki brzegowe I rodzaju na oddalonych granicach sztucznych oraz Wiśle, warunkiem II rodzaju $(\mathrm{Q}=0)$ symulowano występujący lokalnie obszar bezwodny. Przyjęto, że zasilanie infiltracyjne, w zależności od warunków litologicznych strefy przypowierzchniowej, wynosi $55-120 \mathrm{~mm} /$ rok. W procesie tarowania modelu uzyskano zadowalającą zgodność pomierzonych stanów wód ze stanami obliczonymi (w otoczeniu budynku maksymalna różnica tych stanów była mniejsza od $0,15 \mathrm{~m}$, a średnia wynosiła 0,06 m). Obliczenia wykonywano względem średnich stanów wód podziemnych.

Wyniki prognostycznych zmian strumienia filtracji, obliczone dla przyjętego do realizacji wariantu fundamentowania, wskazywały na to, że na etapie eksploatacji obiektu wielkości zmian stanów wód podziemnych będą różne na kierunku dopływu i odpływu wód podziemnych (ryc. 4). Na kierunku dopływu wód podziemnych nastąpi niewielkie podniesienie stanów wód podziemnych (do ok. $+0,06 \mathrm{~m}$ - efekt tamy), natomiast na kierunku odpływu wód podziemnych - obniżenie stanów (wynoszące do $-0,05 \mathrm{~m}$ - strefa cienia). Łącznie prognozowano trwałą zmianę stanów wód podziemnych na skutek wykonania podziemnej części budynku na ok. $0,11 \mathrm{~m}$, tj. znacząco poniżej amplitudy naturalnych, sezonowych wahań poziomu wód podziemnych.

\section{Monitoring stanów wód}

Pomiary stanów wód prowadzono od marca 2014 r. do października 2016 r. w 10 piezometrach (8 na terenie budowy oraz 2 oddalonych od niej o kilkaset metrów: w 1 na dopływie i 1 na odpływie wód podziemnych) oraz w 3 wodowskazach zainstalowanych na Stawach Kellera (ryc. 5). Częstotliwość obserwacji dostosowywano do rejestrowanych zmian hydrodynamicznych oraz postępu robót budowlanych. Wykonano 107 pomiarów stanów wód podziemnych przed rozpoczęciem budowy oraz 74 po zre- alizowaniu inwestycji. Celem tych badań było określenie głębokości zwierciadła wód podziemnych na potrzeby sterowania odwodnieniem budowlanym wykopu oraz ocena zasięgu i wielkości wpływu odwadniania na środowisko, ze szczególnym uwzględnieniem stawów i pomników przyrody znajdujących się w parku Stawy Kellera.

Przed rozpoczęciem prac zwierciadło wód podziemnych w rejonie budowy Słodowiec City znajdowało się na poziomie 92,6 m n.p.m., natomiast w okolicach Stawów Kellera na poziomie 84,8 m n.p.m. - we wszystkich punktach pomiarowych ok. $0,5 \mathrm{~m}$ powyżej ustalonych stanów średnich. W trakcie budowy na skutek robót odwodnieniowych wokół wykopu stany wód podziemnych w otoczeniu obiektu w pierwszej fazie uległy niewielkiemu obniżeniu, a następnie po około 3 miesiącach osiągnęły stany minimalne, wynoszące średnio ok. 91,7 m n.p.m. Po wyłączeniu odwodnienia nastapił proces odbudowy stanów wód podziemnych. Po upływie miesiąca od wyłączenia odwodnienia położenie zwierciadła wód podziemnych w rejonie budynku zarejestrowano na wysokości 92,1 m n.p.m. i zakończono pomiary.

Analizę zmian stanów wód podziemnych przeprowadzono w przekrojach (P6-P5, P7-P1, P4-P3 i P8-P2), usytuowanych wzdłuż linii prądu wód podziemnych (ryc. 5). Obserwacje lokalne prowadzono w piezometrach usytuowanych na dopływie wód podziemnych do obiektu: P4, P6, P7 i P8 oraz w piezometrach zlokalizowanych na odpływie z obiektu (ryc. 6): P1, P2 i P5 (piezometry pomiędzy obiektem, a tunelem metra) oraz P3 (za tunelem metra).

Stany wód podziemnych w punktach monitoringowych usytuowanych $\mathrm{w}$ pobliżu obiektu porównano ze stanami obserwowanymi rejonowo: w piezometrze 1179P, usytuowanym ok. $700 \mathrm{~m} \mathrm{w}$ kierunku południowo-wschodnim od obiektu (na dopływie wód), i w piezometrze 968P, zlokalizowanym w rejonie Stawów Kellera, w odległości ok. 500 m od obiektu (na odpływie wód). Obserwacje w piezometrach rejonowych, zlokalizowanych w dalszej odległości od obiektu, wykorzystano do oceny naturalnych zmian stanów wód podziemnych (ryc. 6).

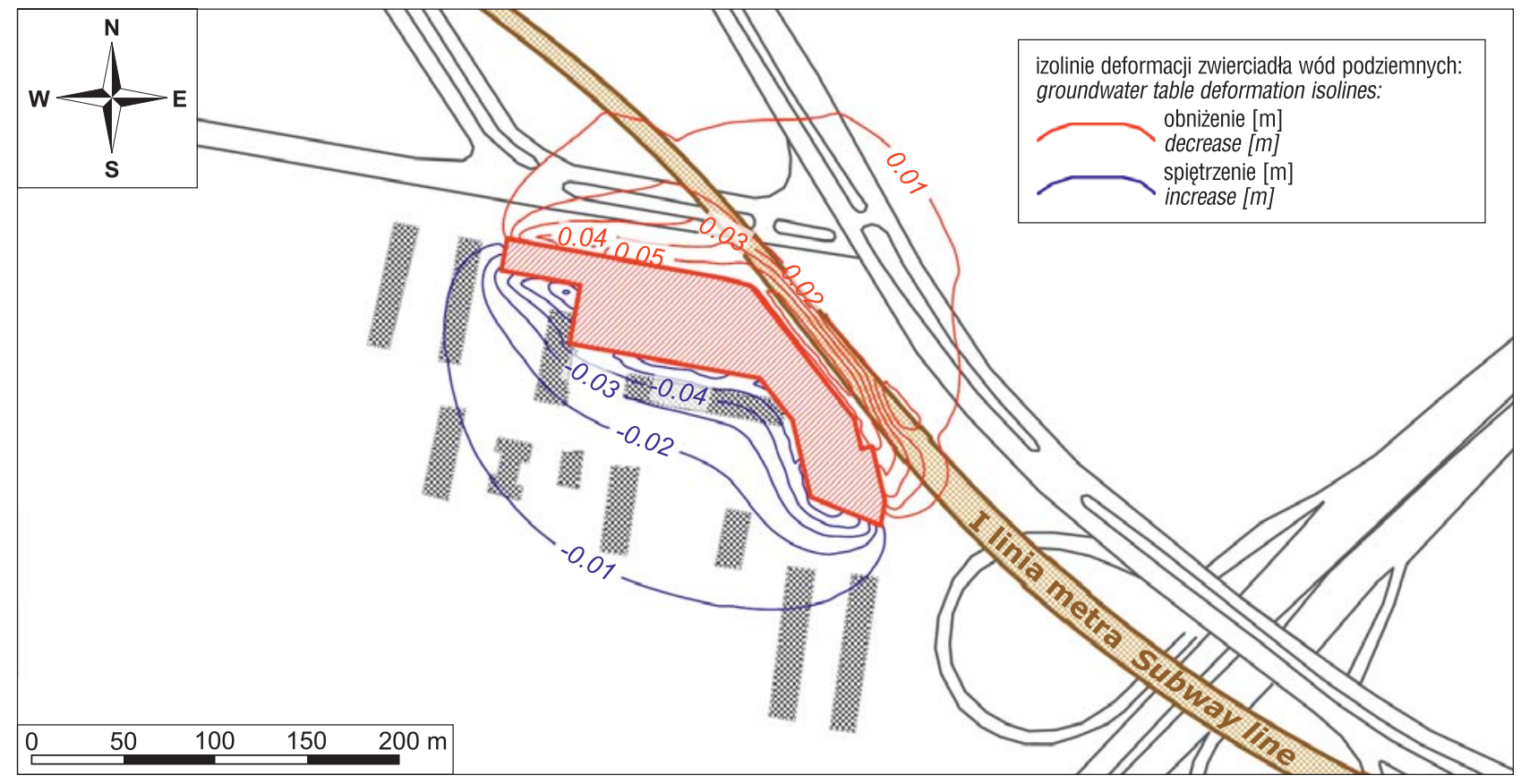

Ryc. 4. Prognoza modelowa deformacji stanów wód podziemnych na skutek budowy obiektu Fig. 4. Model forecast of groundwater level deformation due to the construction of the object 


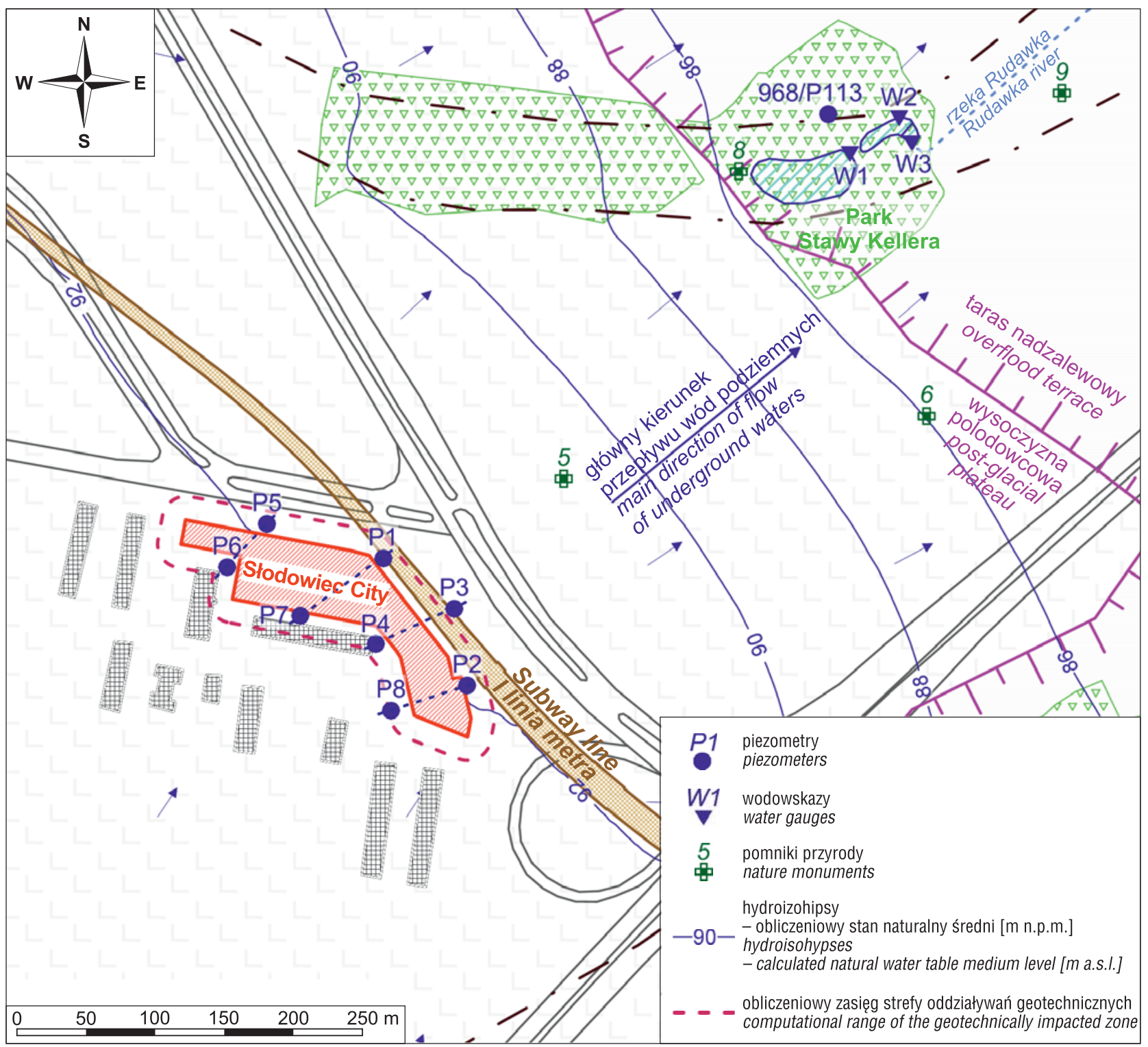

Ryc. 5. Mapa dokumentacyjna obszaru badań

Fig. 5. Documentation map of the study area

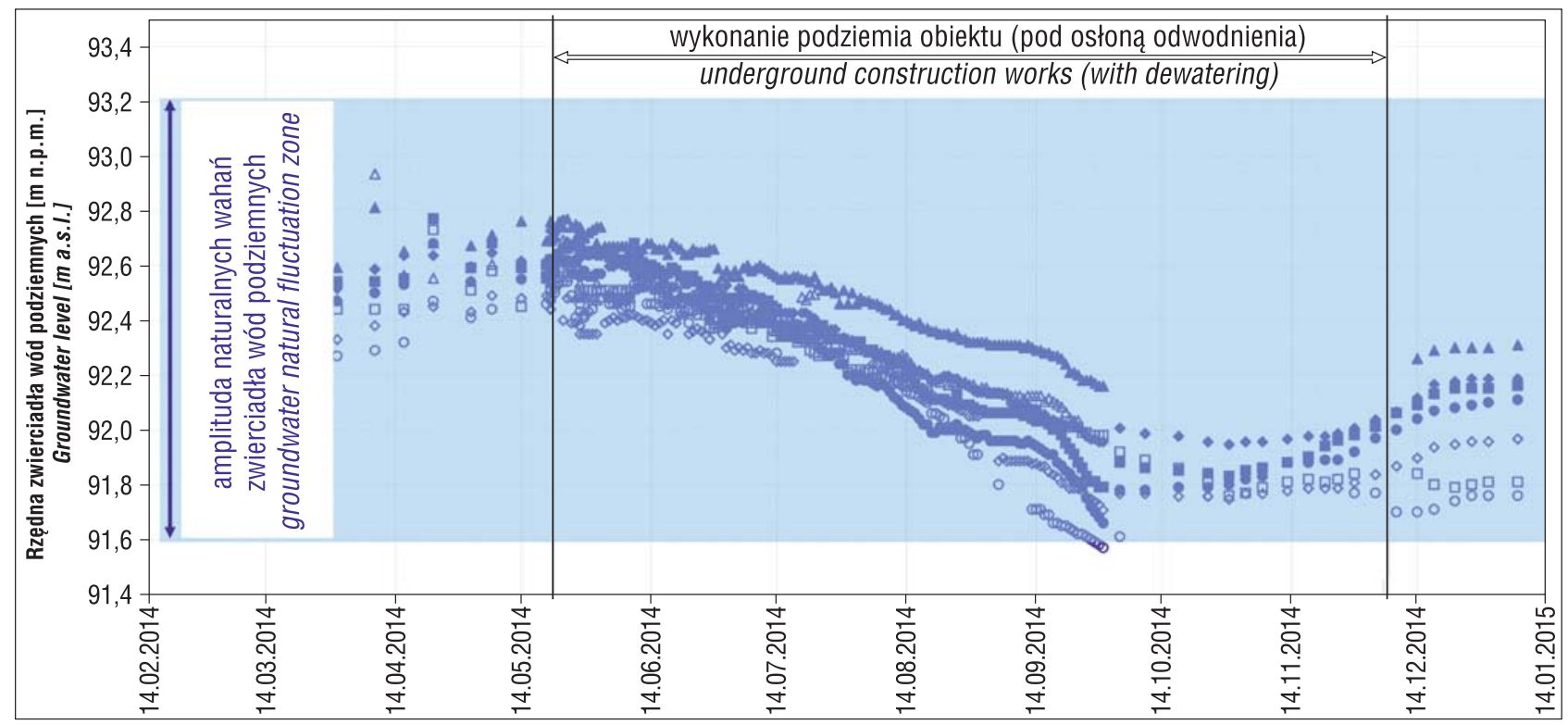

Ryc. 6. Stany wód podziemnych obserwowane na tle amplitudy wahań naturalnych

Fig. 6. Groundwater levels observed against the amplitude of natural fluctuations 


\section{ANALIZA WYNIKÓW I DYSKUSJA}

Po zbudowaniu podziemnej części bloku Słodowiec City stany wód podziemnych obserwowane w lokalnej sieci monitoringowej utrzymywały się na niższym poziomie od początkowych o ok. $0,5 \mathrm{~m}$ (tab. 1). Przestrzenny rozkład różnic stanów wód podziemnych wskazuje, że na dopływie do obiektu uległy one obniżeniu średnio o $0,4-0,6 \mathrm{~m}$, a na odpływie o 0,5-0,8 m (ryc. 7), co oznacza, że na linii prądu wód podziemnych we wszystkich obserwowanych punktach nastapił wzrost spadku hydraulicznego średnio o 0,18 do $0,38 \%$.

Na podstawie analizy stanów wód podziemnych mierzonych w punktach monitoringowych przed budową i po jej zakończeniu (ryc. 8) stwierdzono, że największe zmiany stanów nastapiły w okolicy wschodniego skrzydła budynku Słodowiec City (punkty P2 i P3, przyrost $>0,2 \mathrm{~m}$ ), $\mathrm{w}$ bezpośrednim sąsiedztwie tunelu metra. Od strony zachodniej różnice te są znacznie mniejsze. Po stronie zachodniej największe różnice stanów wód podziemnych stwierdzono za tunelami metra, a nie przy samym obiekcie (przekrój P4-P1-P3). Odwrotną sytuację zaobserwowano po stronie wschodniej (przekrój P4-P2-P3), gdzie po zakończeniu budowy spadek hydrauliczny pod tunelami metra zmniejszył się, a główny przyrost spadku obserwowano pomiędzy obiektem a tunelami (ryc. 9). W piezometrach usytuowanych w odległości kilkuset metrów od obiektu odnotowano niewielkie różnice stanów wód podziemnych przed budową i po jej zakończeniu (tab. 1).

Zaobserwowane różnice stanów wód podziemnych są skutkiem wbudowania w strumień tych wód podziemnej części budynku Słodowiec City oraz skumulowanego oddziaływania innych inwestycji, przede wszystkim tuneli metra. Tylko niewielka część tych zmian może być wynikiem różnic w zasilaniu poziomu wodonośnego.

Na podstawie analizy map hydroizohips stwierdzono, że po wzniesieniu budynku nastąiły lokalne zmiany kierunków przepływu wód podziemnych (ryc. 9), szczególnie

Tab. 1. Charakterystyka sieci i wyniki monitoringu hydrogeologicznego

Table 1. Network characteristics and results of hydrogeological monitoring

\begin{tabular}{|c|c|c|c|c|c|c|c|c|c|c|c|}
\hline \multicolumn{12}{|c|}{ Punkty monitoringowe / Monitoring points } \\
\hline \multirow{2}{*}{\multicolumn{2}{|c|}{$\begin{array}{l}\text { Lokalizacja } \\
\text { Location }\end{array}$}} & \multicolumn{8}{|c|}{ lokalne / local } & \multicolumn{2}{|c|}{ rejonowe / district } \\
\hline & & \multicolumn{4}{|c|}{$\begin{array}{l}\text { na doplywie } \\
\text { inflow }\end{array}$} & \multicolumn{4}{|c|}{$\begin{array}{l}\text { na odplywie } \\
\text { outflow }\end{array}$} & $\begin{array}{c}\text { na doplywie } \\
\text { inflow } \\
(-0,7 \mathrm{~km})\end{array}$ & $\begin{array}{c}\text { na odplywie } \\
\text { outflow } \\
(+0,5 \mathrm{~km})\end{array}$ \\
\hline \multicolumn{2}{|c|}{ Nr punktu / Point number } & $\mathbf{P 4}$ & P6 & $\mathbf{P 7}$ & P8 & P1 & $\mathbf{P 2}$ & P3 & P5 & 1179/1/P1 & 968/P113 \\
\hline \multicolumn{2}{|c|}{ Glębokość / Depth [m] } & 8 & 8 & 8 & 8 & 8 & 8 & 8 & 8 & 5 & 5 \\
\hline \multirow{2}{*}{$\begin{array}{c}\text { Średnie stany } \\
\text { wód podziemnych } \\
\text { [m n.p.m.] } \\
\text { Average } \\
\text { groundwater levels } \\
\text { [m a.s.l.] }\end{array}$} & $\begin{array}{c}\text { przed budową } \\
\text { before construction } \\
\text { (14.03-14.05.2014 r., } \\
19 \text { serii pomiarowych) }\end{array}$ & 92,45 & 92,69 & 92,61 & 92,60 & 92,38 & 92,52 & 92,39 & 92,59 & 95,24 & 84,72 \\
\hline & \begin{tabular}{|c} 
po budowie \\
after construction \\
$(14.12 .2014 \mathrm{r}-16.10 .2015 \mathrm{r}$. \\
14 serii pomiarowych $)$
\end{tabular} & 91,99 & 92,29 & 92,08 & 92,06 & 91,93 & 91,81 & 91,63 & b.d. & 95,11 & 84,82 \\
\hline \multicolumn{2}{|c|}{$\begin{array}{l}\text { Różnica stanów } \\
\text { Level differences }[\mathrm{m}]\end{array}$} & $-0,46$ & $-0,40$ & $-0,53$ & $-0,54$ & $-0,45$ & $-0,71$ & $-0,76$ & b.d. & $-0,13$ & $+0,10$ \\
\hline
\end{tabular}

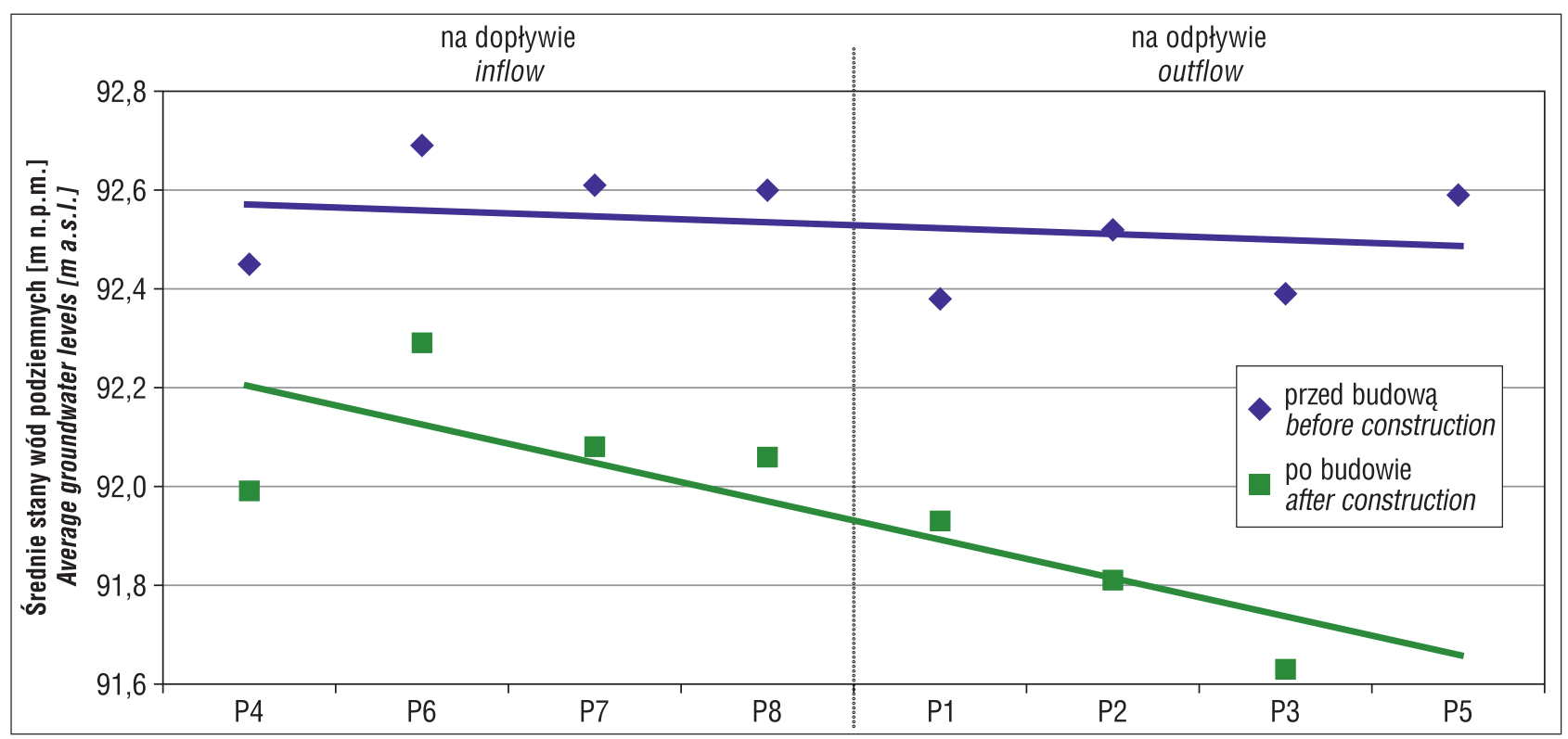

Ryc. 7. Średnie stany wód podziemnych przed rozpoczęciem budowy obiektu i po jej zakończeniu

Fig. 7. Average groundwater levels before and after the implementation of the object 
w okolicach środkowej części obiektu. Ta lokalna deformacja układu hydroizohips jest niewielka, a zasadniczy kierunek przepływu wód podziemnych pozostał bez zmian.
Wyniki obserwacji zmian stanów wód podziemnych potwierdzają niewielki zasięg oddziaływania odwodnienia wykopu oraz szybką odbudowę stanów wód po zakończeniu budowy Słodowiec City. Prawdopodobnie doszło do

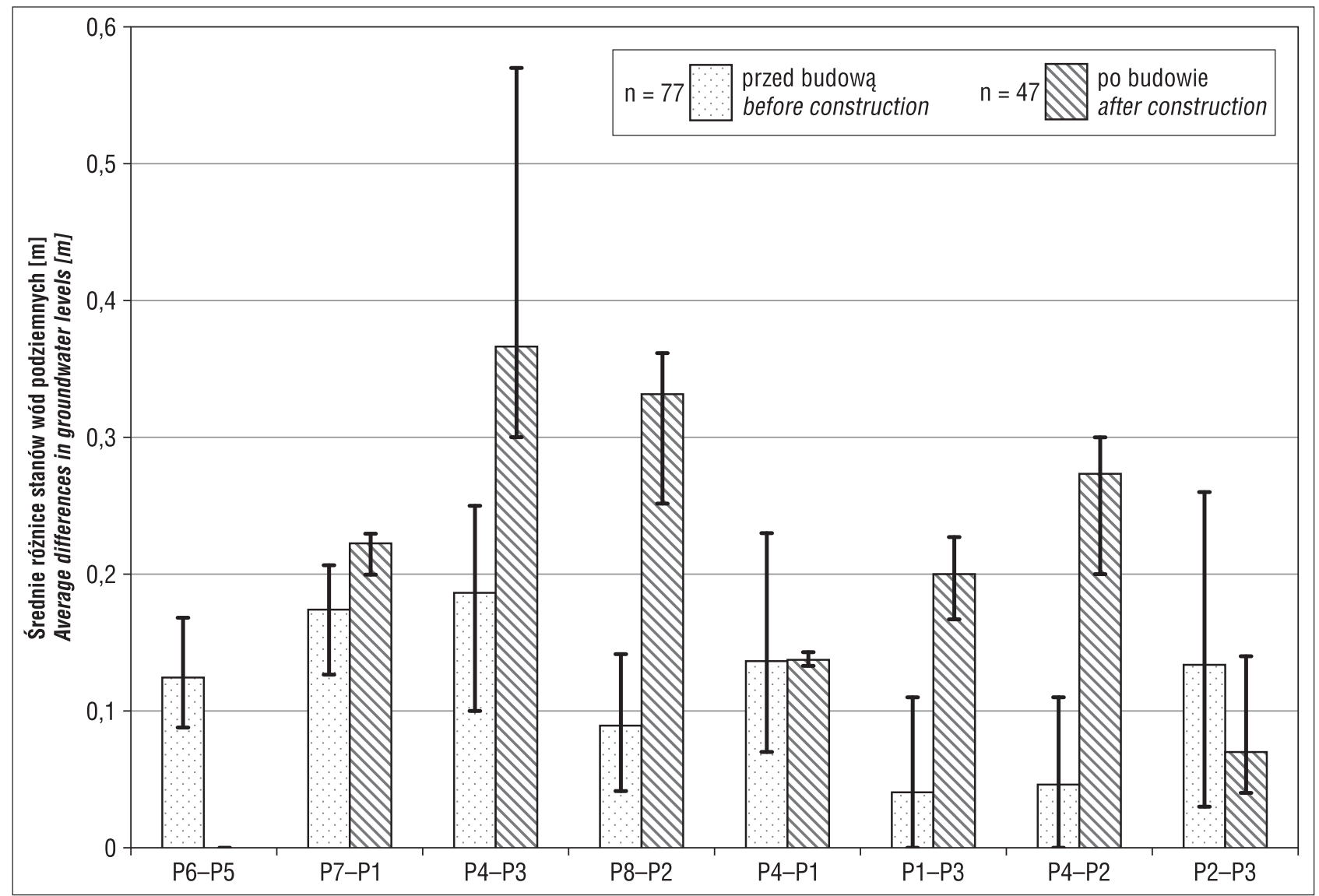

Ryc. 8. Średnie różnice stanów wód podziemnych na przekrojach badawczych

Fig. 8. Average differences in groundwater levels on research cross-sections

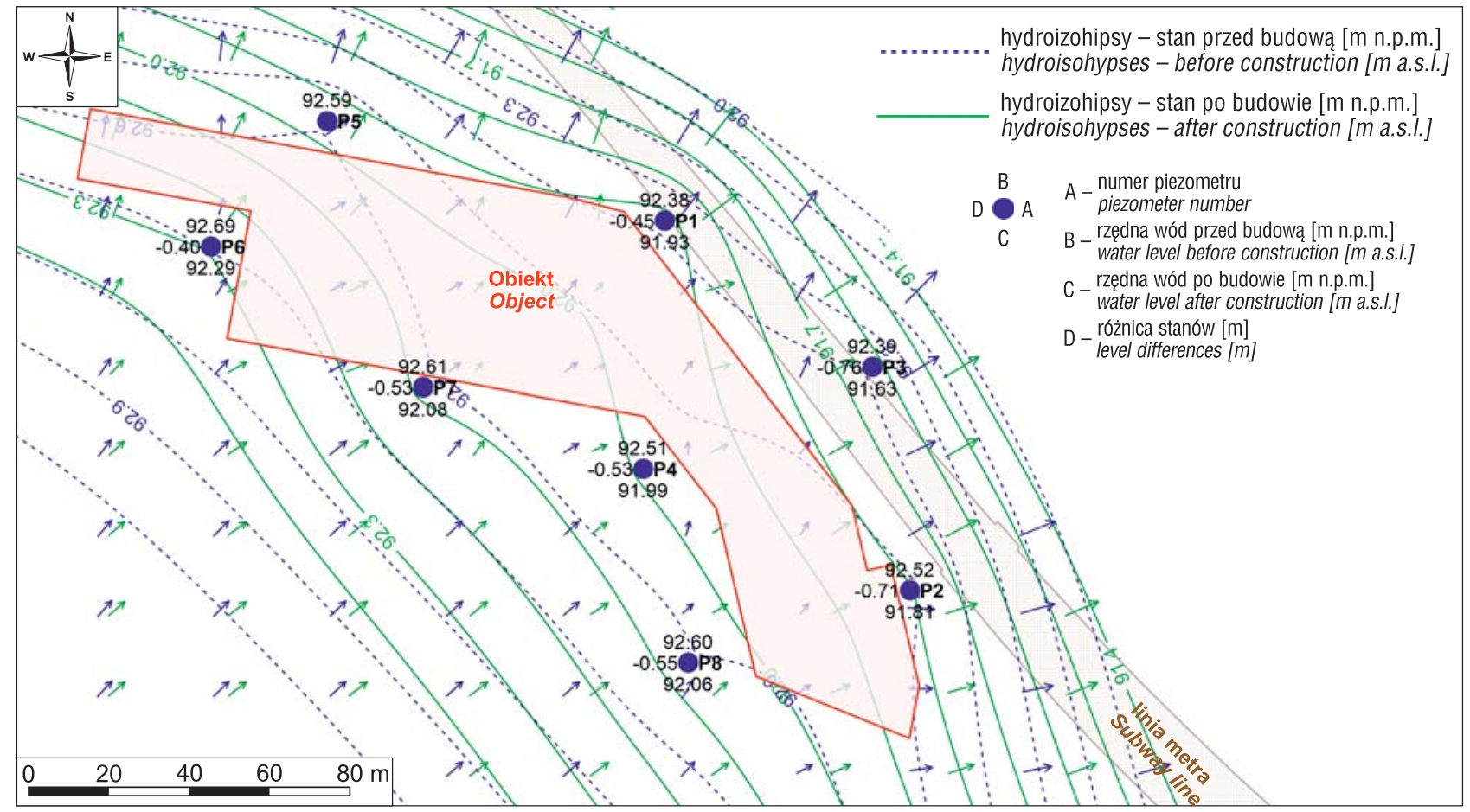

Ryc. 9. Mapa hydroizohips wokół budynku Słodowiec City przed rozpoczęciem i po zakończeniu prac budowlanych Fig. 9. Hydroisohypses map before and after construction of the object 
kumulacji oddziaływania innych obiektów budowlanych na przepływ wód podziemnych, co potwierdzają różnice stanów wód w piezometrach usytuowanych w różnej odległości od tunelu metra.

Nie stwierdzono oddziaływania budynku Słodowiec City na obszar wrażliwy przyrodniczo (park Stawy Kellera): zarówno na stan wód podziemnych (tab. 1; punkt 968/P113), jak i powierzchniowych.

Porównanie prognoz z wynikami monitoringu hydrogeologicznego prowadzonego $\mathrm{w}$ trakcie i po zakończeniu budowy wskazuje na odmienny rozkład odkształceń siatki filtracyjnej - większe odkształcenia niż zakładano nastąpiły od wschodniej strony budynku. Natomiast pomierzona średnia amplituda zmian poziomu wód była taka sama jak prognozowana - ok. 0,1 m.

W efekcie realizacji tej inwestycji nastapił nieznaczny przyrost spadków hydraulicznych, zwłaszcza po wschodniej stronie nowo wybudowanego obiektu (blisko tunelu metra), co wskazuje na nakładanie się oddziaływań obu obiektów - oddziaływanie skumulowane.

\section{WNIOSKI}

Wyniki badań wskazują, że wbudowanie podziemnej bryły budynku Słodowiec City w strumień wód podziemnych spowodowało nieznaczne deformacje jego struktury. Nastąpiły niewielkie zmiany kierunku filtracji i prędkości przepływu wód. Efekt ten spotęgowało zagęszczenie podziemnej zabudowy w okolicy budynku (m.in. tunel metra). Jednak mimo superpozycji oddziaływań nie okazały się one znaczące - pozostały w zakresie zmian dopuszczalnych, nie powodujących szkodliwego wpływu na otoczenie, w tym na wrażliwe środowisko wokół Stawów Kellera.

W obszarach zurbanizowanych, wskutek jednoczesnej realizacji i eksploatacji licznych inwestycji, określenie zakresu zmian stanów wód podziemnych w stosunku do fluktuacji naturalnych jest utrudnione. Hydrogeologiczne uwarunkowania fundamentowania obiektów głęboko posadawianych, w tym zmiany stanów wód podziemnych wynikające z zabudowy części podziemnych, należy analizować na etapie projektowania oraz monitorować w trakcie budowy inwestycji oraz po jej zakończeniu.

$\mathrm{Na}$ szczególną uwagę zasługują obserwacje realizowane w lokalnej, dedykowanej sieci monitoringowej. Za wartościowe uznaje się wykonywanie ukierunkowanych badań hydrogeodynamicznych (próbnych wymuszeń o zakresie ustalonym na podstawie modelowej prognozy ich przebiegu). Stosowanie metod modelowych wespół z monitoringiem realizacji inwestycji umożliwia wskazanie przestrzennego i czasowego zasięgu oddziaływania obiektu, a w przypadku interakcji wielu inwestycji określenie wpływu poszczególnych obiektów na warunki wodne oraz określenie wpływu skumulowanego. Taki tok badań stanowi skuteczne, wręcz podstawowe, narzędzie w procesie projektowania $\mathrm{i}$ realizacji podziemnej zabudowy $\mathrm{w}$ obszarach miejskich, a także w aspekcie przestrzennego planowania aglomeracji.

\section{LITERATURA}

BURZYŃSKI K., SZPAKOWSKI W. 2010 - Wpływ uproszczeń modelu numerycznego na symulację odwodnienia budowlanego. Biul. Państw. Inst. Geol., 442: 9-14.
CHMIELEWSKI R., OPĘCHOWSKI K., GÓRNICKA K., WOŁEK M. 2012 - Uwarunkowania hydrogeologiczne fundamentowania budynku mieszkalnego wielorodzinnego z usługami, handlem, częścią administracyjną oraz garażami podziemnymi na działkach o nr ewidencyjnych 24 , 26, 30 31, 33 z obrębu 7-05-14 przy ul. Słowackiego róg Żeromskiego na terenie dzielnicy Bielany m.st. Warszawy. Arch. Geosystem W. Opęchowski.

DAWIDOWSKI J., MISIUREK F. 2003 - Dokumentacja geologiczno-inżynierska i hydrogeologiczna dla I linii metra na odcinku od stacji A19 Marymont do stacji A23 Młociny wraz z torami odstawczymi. Arch. Metroprojekt Sp. z o.o.

DĄBROWSKI S. 1997 - Uwagi dotyczące modeli matematycznych dla potrzeb hydrogeologii. Materiały XII Sympozjum pt. Modelowanie matematyczne $w$ hydrogeologii $i$ ochronie środowiska, Częstochowa, 20-21.11.1997 r.

DĄBROWSKI S., SZYMANKO J. 1987 - Problemy zastosowania modelowania matematycznego w prognozowaniu skutków wpływu budowy metra warszawskiego na wody podziemne. Prz. Geol., 35 (2): 94-95.

DĄBROWSKI S., WITCZAK S. 2011 - Metodyka modelowania matematycznego w badaniach i obliczeniach hydrogeologicznych: Poradnik Metodyczny. Min. Środ.

DING G., JIAO J., ZHANG D. 2008 - Modelling Study on the Impact of Deep Building Foundations on the Groundwater System. Hydrol. Proc., 22 (12): 1857-1865; https://doi.org/10.1002/hyp.6768.

HARBAUGH A.W. 2005 - MODFLOW-2005?: The U.S. Geological Survey Modular Ground-Water Model-the Ground-Water Flow Process. U.S. Geological Survey Techniques and Methods, 6-A16.

JEŻ P., KSIĄŻYŃSKI K., PRYSTAJ A., KRÓL Z. 1995 - Modelowanie wpływów antropogenicznych na stosunki wodne terenów miejskich. [W:] Współczesne problemy hydrogeologii, Wyd. Profil, Kraków-Krynica, 307-312.

JIAO J.J., LEUNG C., DING G. 2008 - Changes to the groundwater system, from 1888 to present, in a highly-urbanized coastal area in Hong Kong, China. Hydrogeology J., 16: 1527-1539.

KAZIMIERSKI B., PACZYŃSKI B. 2005 - Monitoring wód podziemnych aglomeracji miejskich. [W:] Hydrogeologia obszarów zurbanizowanych i uprzemysłowionych, Wyd. UŚl., Sosnowiec, 2: $71-80$.

KROGULEC E. 1997 - Numeryczna analiza struktury strumienia filtracji w strefie krawędziowej poziomu błońskiego (Kotlina Warszawska). Wyd. UW.

ŁUKASIK S., GODLEWSKI T., SOKOŁOWSKA M., JAŚKIEWICZ K., WSZĘDYRÓWNY-NAST M., WITOWSKI M. 2011 - Dokumentacja geologiczno-inżynierska do projektu architektoniczno-budowlanego dla inwestycji na działce pomiędzy ulicami Żeromskiego, Słowackiego i Słodowiec w Warszawie. Arch. Instytutu Techniki Budowlanej.

MAŁECKI J. 2013 - Wpływ urbanizacji na stany charakterystyczne zwierciadła wód podziemnych - analiza wyników badań prowadzonych na stacji naukowo-badawczej Wydziału Geologii UW w Warszawie. Biul. Państw. Inst. Geol., 456: 377-383.

OPĘCHOWSKI W. 2005 - Odwodnienia budowlane wykopów na przykładzie obiektów zrealizowanych w Warszawie. [W:] XX Ogólnopolska Konferencja Warsztat pracy projektanta konstrukcji, Wisła-Ustroń 2005, Polski Związek Inżynierów i Techników Budownictwa, Oddział w Krakowie: 297-316.

OPECHOWSKI W. 2010 - Uwarunkowania hydrogeologiczne głębokiego fundamentowania. [W:] Seminarium Ściany szczelinowe. IBDiM i PZWFS: 107-131.

PN-EN 1997-1:2008-05P Eurokod 7: Projektowanie geotechniczne. Część 1: Zasady ogólne. n.d.

POWERS J.P., HERRIDGE C.J., CORWIN A.B., SCHMALL P.C., KAECK W.E. 2007 - Construction Dewatering and Groundwater Control: New Methods and Applications. Wiley, Wiley series of practical construction guides.

SUJKOWSKI Z., RÓŻYCKI Z. 1936 - Mapa geologiczna Warszawy w skali 1: 20 000. Zarząd Miejski w m.st. Warszawie.

SZYMANKO J. 1987 - Zastosowanie modelowania matematycznego przy projektowaniu odwodnień wykopów metra na przykładzie stacji A-10. Prz. Geol., 35, 7: 376-380.

ZAJDEL J., ZAWADZKI M. 1987 - Badania hydrowęzłowe na terenie Pola Mokotowskiego w Warszawie. Prz. Geol., 35 (2): 96-98.

ZHOU N., A. VERMEER P., LOU R., TANG Y., JIANG S. 2010 Numerical Simulation of Deep Foundation Pit Dewatering and Optimization of Controlling Land Subsidence. Engin. Geol., 114: 251-260; https://doi.org/10.1016/j.enggeo.2010.05.002.

Praca wpłynęła do redakcji 7.02.2019 r.

Akceptowano do druku 20.03.2019 r. 